\title{
DZIELENIE SIĘ WIEDZĄ W PRZEDSIĘBIORSTWACH - WYBRANE PROBLEMY I UWARUNKOWANIA
}

\begin{abstract}
W artykule podjęto rozważania dotyczące problematyki i uwarunkowań dzielenia się wiedzą w przedsiębiorstwach. Na podstawie przeprowadzonego studium literatury przedstawiono wieloaspektowość, złożoność, a zarazem niejednoznaczność wpływu czynników indywidualnych, interpersonalnych, organizacyjnych i technologicznych na dzielenie się wiedzą. Następnie zaprezentowano wyniki badań pierwotnych, których celem było określenie stopnia zaawansowania wybranych praktyk dotyczących dzielenia się wiedzą w przedsiębiorstwach funkcjonujących w Polsce, a w szczególności uzyskanie odpowiedzi na pytanie, czy intensywność współpracy międzyorganizacyjnej oraz postrzegana niepewność otoczenia mają wpływ na zaawansowanie dzielenia się wiedzą.

W przeprowadzonych analizach wykazano, że zarówno intensywność współpracy międzyorganizacyjnej, jak i poziom postrzeganej niepewności otoczenia istotnie wpływają na zróżnicowanie zaawansowania badanych praktyk dotyczących dzielenia się wiedzą. Intensywność współpracy międzyorganizacyjnej ma największy pozytywny wpływ na zakres wykorzystywania systemów informatycznych ułatwiających dzielenie się wiedzą, zapewniania pracownikom udziału w szkoleniach i programach rozwoju, a także stosowania zachęt dla pracowników do dzielenia się wiedzą. Postrzegana niepewność otoczenia w największym stopniu wpływa na zakres stosowania zachęt dla pracowników do dzielenia się wiedzą, wykorzystywania systemów informatycznych ułatwiających dzielenie się wiedzą oraz pełnienia przez pracowników wyższego szczebla roli mentorów dla młodszych pracowników.

Reasumując przeprowadzone badania, stwierdzono, że rozwój praktyki organizacyjnego dzielenia się wiedzą nie tylko usprawnia wymianę i upowszechnianie w przedsiębiorstwie wiedzy wcześniej zakumulowanej przez jego pracowników, ale również poprawia skuteczność absorpcji wiedzy zewnętrznej pozyskiwanej w ramach współpracy międzyorganizacyjnej. Stanowi to istotną przesłankę dla przetrwania przedsiębiorstwa w turbulentnym i nieprzewidywalnym otoczeniu ze względu na znaczenie zaawansowania tych procesów dla jakości i szybkości wprowadzania innowacji, będących najczęściej decydującym źródłem uzyskiwania i utrzymywania przewagi konkurencyjnej.

Słowa kluczowe: dzielenie się wiedzą, uwarunkowania dzielenia się wiedzą, współpraca międzyorganizacyjna, niepewność otoczenia, przedsiębiorstwo
\end{abstract}

\section{WPROWADZENIE}

W gospodarce opartej na wiedzy kluczową rolę dla przetrwania przedsiębiorstw w dynamicznie zmieniającym się otoczeniu odgrywają ich zasoby i kompetencje. Szczególne znaczenie dla uzyskiwania i utrzymywania przewagi konkurencyjnej mają zasoby wiedzy. W związku z tym przedmiotem coraz większego zainteresowania badaczy i praktyków zarządzania staje się problematyka identyfikowania, przechwytywania, tworzenia

${ }^{1}$ Dr inż. Adam Ryszko, Wydział Organizacji i Zarządzania, Politechnika Śląska, ul. Roosevelta 32, 41-800 Zabrze, tel.: 322777474 , e-mail: adam.ryszko@polsl.pl 
i akumulowania wiedzy. W odniesieniu do skuteczności i efektywności funkcjonowania przedsiębiorstw niezmiernie istotne miejsce w omawianym obszarze zajmuje dzielenie się wiedzą między ich pracownikami, komórkami organizacyjnymi czy zespołami roboczy$\mathrm{mi}^{2}$. Badania empiryczne obejmujące problematykę dzielenia się wiedzą w przedsiębiorstwach charakteryzują się cennymi walorami poznawczymi i utylitarnymi. Pomimo że jest ona w Polsce wciąż słabo rozpoznana, jednocześnie dotychczasowe wyniki analiz wskazują, że w obszarze zarządzania wiedzą w przedsiębiorstwach kluczową rolę odgrywają innowacje dotyczące dzielenia się wiedzą ${ }^{3}$. W związku z tym celowe wydaje się wypełnienie istniejącej w tym zakresie luki.

W ramach rozważań podjętych w niniejszym artykule przybliżono problematykę i uwarunkowania dzielenia się wiedzą w przedsiębiorstwach. Dokonano przeglądu wyników badań obejmujących analizę wpływu czynników indywidualnych, interpersonalnych, organizacyjnych i technologicznych na dzielenie się wiedzą. Następnie zaprezentowano wyniki badań pierwotnych, których celem było określenie poziomu zaawansowania wybranych praktyk dotyczących dzielenia się wiedzą w przedsiębiorstwach funkcjonujących w Polsce, a w szczególności uzyskanie odpowiedzi na pytanie, czy zakres współpracy międzyorganizacyjnej oraz postrzegana niepewność otoczenia wpływają na intensywność dzielenia się wiedzą.

\section{ISTOTA I UWARUNKOWANIA DZIELENIA SIE WIEDZA W PRZEDSIĘBIORSTWACH}

Dzielenie się wiedzą w przedsiębiorstwach polega na wymianie lub upowszechnianiu wiedzy pomiędzy pracownikami lub ich grupami. Proces ten przyczynia się do tworzenia nowej wiedzy, jednocześnie ułatwiając jej zastosowanie w praktyce ${ }^{4}$. Obejmuje ono podaż i popyt na nową wiedzę, co oznacza, że konieczne jest, by uczestniczyły w nim jednostki gotowe do przekazania posiadanej wiedzy, a także jednostki skłonne do jej pozyskania ${ }^{5}$.

W literaturze przedmiotu występują różnorodne ujęcia uwarunkowań wpływających na proces dzielenia się wiedzą pomiędzy pracownikami. Wśród najczęściej spotykanych można wyróżnić czynniki indywidualne, interpersonalne, organizacyjne i technologiczne.

Podstawą wyodrębnienia uwarunkowań indywidualnych jest założenie, że dzielenie się wiedzą zależy od cech poszczególnych osób, w tym ich motywacji, przekonań, wykształcenia czy doświadczenia. Rezultaty badań w tym zakresie nie są jednak jednoznaczne. Angel Cabrera, William C. Collins i Jestis F. Salgado dowiedli, że pracownicy, którzy uznają, że posiadają użyteczną wiedzę, są bardziej zaangażowani w proces dzielenia się wiedzą. Główną rolę odgrywa otwartość pracowników na zdobywanie nowych doświadczeń, która skutkuje poszukiwaniem pomysłów i inspiracji u innych osób ${ }^{6}$. Z kolei Molly

\footnotetext{
${ }^{2}$ M. Alavi, D.E. Leidner, Knowledge management and knowledge management systems: conceptual foundations and research issues, „MIS Quarterly” 25/1 (2001), s. 107-136.

${ }^{3}$ A. Bitkowska, Innowacje w zarządzaniu wiedza w sektorze MSP, [w:] Podejście innowacyjne w zarządzaniu, red. R. Nowacki, M.W. Staniewski, Difin, Warszawa 2010, s. 125-126.

${ }^{4}$ B. van den Hooff, F.D.L. van Weenen, Committed to share: commitment and CMC use as antecedents of knowledge sharing, „Knowledge and Process Management” 11/1 (2004), s. 13-24.

5 A. Ardichvill, V. Page, T. Wentling, Motivation and barriers to participation in virtual knowledge-sharing communities of practice, ,Journal of Knowledge Management” 7/1 (2003), s. 64-77.

${ }^{6}$ A. Cabrera, W.C. Collins, J.F. Salgado, Determinants of individual engagement in knowledge sharing, ,International Journal of Human Resource Management” 17/2 (2006), s. 245-264.
} 
McLure Wasko i Samer Faraj nie znaleźli istotnych zależności pomiędzy poziomem samooceny posiadanej wiedzy eksperckiej a intensywnością dzielenia się wiedzą. Dowiedli natomiast, że pracownicy są zmotywowani do dzielenia się wiedzą, gdy uważają, że warto ponieść związany z tym wysiłek i przez to pomóc innym ${ }^{7}$. Wyniki innych badań wykazały, że poczucie lęku i niepokój wynikający ze strachu przed nieprzychylnym odbiorem przekazywanej wiedzy są negatywnie powiązane $\mathrm{z}$ intensywnością dzielenia się wiedzą ${ }^{8}$.

$\mathrm{Na}$ dzielenie się wiedzą między członkami danego zespołu istotnie wpływają cechy interpersonalne jego członków oraz charakterystyka samego zespołu. Badania dowodzą, że im dłużej jest formowany zespół i im wyższy poziom jego spójności, tym większe prawdopodobieństwo dzielenia się wiedzą między jego członkami ${ }^{9}$. Na dzielenie się wiedzą wpływają również zróżnicowanie członków zespołu. Abhoy K. Ojha wykazał, że członkowie zespołu, którzy uznają się za mniejszość ze względu na płeć, stan cywilny czy poziom edukacji, są mniej chętni do dzielenia się wiedzą z pozostałymi członkami zespo$\mathfrak{\jmath u}^{10}$. W innym badaniu wykazano, że zespoły badawczo-rozwojowe, w których wskaźnik udziału kobiet jest wysoki, są bardziej skłonne do dzielenia się wiedzą niż zespoły, w których wskaźnik ten jest niższy ${ }^{11}$. Niezmiernie istotne dla dzielenia się wiedzą w zespole jest zaufanie. Pracownicy dzielą się wiedzą częściej, gdy uznają, że inni członkowie zespołu są uczciwi, sprawiedliwi i przestrzegają zasad ${ }^{12}$. Pomimo wskazywanej w badaniach pozytywnej relacji pomiędzy zaufaniem a dzieleniem się wiedzą, należy pamiętać, że nadmierne zaufanie może przynosić również negatywny skutek. Może ono powodować u potencjalnego użytkownika wiedzy powstrzymywanie się w kwestionowaniu jej praktycznej przydatności, co może prowadzić do niepotrzebnego lub niewłaściwego jej zastosowania $^{13}$.

W kontekście czynników organizacyjnych można między innymi wyróżnić badania związków między wsparciem kierownictwa, strukturą organizacyjną, kulturą organizacyjną czy systemem nagród i zachęt a dzieleniem się wiedzą. Istotność zachęcania najwyższego kierownictwa do dzielenia się wiedzą podkreślają Hsiu-Fen Lin i Gwo-Guang Lee, dowodząc, że jest ono konieczne do tworzenia i utrzymywania przyjaznej dla takich działań kultury organizacyjnej ${ }^{14}$. Równie istotne jest wsparcie najwyższego kierownictwa

\footnotetext{
${ }^{7}$ M.M. Wasko, S. Faraj, Why should I share? Examining social capital and knowledge contribution in electronic networks of practice, ,MIS Quarterly” 29/1 (2005), s. 35-57.

${ }^{8}$ P. Bordia, B.E. Irmer, D. Abusah, Differences in sharing knowledge interpersonally and via databases: The role of evaluation apprehension and perceived benefits, ,European Journal of Work and Organizational Psychology" 15/3 (2006), s. 262-280.

${ }^{9}$ M. Bakker, R.T.A.J. Leenders, S.M. Gabbay, J. Kratzer, J.M.L. van Engelen, Is trust really social capital? Knowledge sharing in product development projects, „,The Learning Organization” 13/6 (2006), s. 594-605.

${ }^{10}$ A.K. Ojha, Impact of team demography on knowledge sharing in software project teams, ,South Asian Journal of Management" 12/3 (2005), s. 67-78.

11 Y.W. Sawng, S.H. Kim, H.S. Han, R\&D group characteristics and knowledge management activities: A comparison between ventures and large firms, „International Journal of Technology Management” 35/1-4 (2006), s. 241-261.

${ }^{12}$ M. Bakker, R.T.A.J. Leenders, S.M. Gabbay, J. Kratzer, J.M.L. van Engelen, op. cit., s. 594-605.

${ }^{13}$ S. Sondergaard, M. Kerr, C Clegg, Sharing knowledge: Contextualising socio-technical thinking and practice, „The Learning Organization” 14/5 (2007), s. 423-435.

${ }^{14}$ H.F. Lin, G.G. Lee, Perceptions of senior managers toward knowledge-sharing behaviour, „Management Decision" 42/1 (2004), s.108-125.
} 
w budowie klimatu organizacyjnego sprzyjającego dzieleniu się wiedzą ${ }^{15}$. Postrzegane przez pracowników wsparcie przełożonego oraz współpracowników i ich zachęcanie do dzielenia się wiedzą nie tylko zwiększają wymianę wiedzy między pracownikami, ale także pozytywnie wpływają na postrzeganą przez nich przydatność takich działań ${ }^{16}$. Wyniki badań wskazują, że dzieleniu się wiedzą sprzyjają niescentralizowane struktury organizacyjne ${ }^{17}$. Istotne jest zapewnienie środowiska pracy, które zachęca do interakcji między pracownikami poprzez wykorzystanie otwartej przestrzeni pracy, stosowanie rotacji stanowisk czy organizowanie nieformalnych spotkań. W celu ułatwienia dzielenia się wiedzą powinno się tworzyć możliwości wystąpienia interakcji między pracownikami, jednak bez uwydatniania ich pozycji w hierarchii organizacyjnej ${ }^{18}$. Szczególne znaczenie dla dzielenia się wiedzą ma kultura organizacyjna. Skuteczne dzielenie się wiedzą jest pozytywnie powiązane z kulturą organizacyjną zachęcającą do tworzenia innowacyjnych pomysłów oraz skupiającą się na wyciąganiu wniosków z poniesionych porażek ${ }^{19}$. Kultura organizacyjna ukierunkowana na indywidualne współzawodnictwo może stanowić barierę dla dzielenia się wiedzą, podczas gdy kultura zorientowana na współpracę zespołową pomaga tworzyć zaufanie, stanowiące niezbędny warunek skutecznego dzielenia się wie$\mathrm{dząq}^{20}$. Stwierdzono ponadto, że kultura organizacyjna podkreślająca zaufanie pomaga złagodzić negatywne skutki postrzeganych kosztów dzielenia się wiedząą . Jedną z podstawowych przeszkód zaś jest brak zachęt do tego typu działań. Przyjmuje się, że zachęty obejmujące nagrody i uznanie znacząco wspierają ten proces ${ }^{22}$. Pomimo przewidywanego pozytywnego wpływu oddziaływania zachęt na dzielenie się wiedzą wyniki badań empirycznych w tym zakresie są jednak niejednoznaczne. Dowiedziono między innymi występowania współzależności między zachętami grupowymi i indywidualnymi oraz ich pozytywnego związku z dzieleniem się wiedzą. Wykazano, że zależność między poziomem nagród grupowych a dzieleniem się wiedzą jest tym silniejsza, im wyższy jest poziom stosowanych w tym zakresie nagród indywidualnych ${ }^{23}$. S. Kim i H. Lee wykazali, że stosowanie sytemu wynagrodzeń uzależnionego od osiąganych wyników przyczynia się do zwiększonego poziomu dzielenia się wiedzą ${ }^{24}$. Należy jednak wskazać wyniki badań,

\footnotetext{
${ }^{15}$ H.F. Lin, Knowledge sharing and firm innovation capability: an empirical study, „International Journal of Manpower" 28/3-4 (2007), s. 315-332.

${ }^{16}$ A. Cabrera, W.C. Collins, J.F. Salgado, op. cit., s. 245-264.

${ }^{17} \mathrm{~S}$. Kim, H. Lee, The impact of organizational context and information technology on employee knowledgesharing capabilities, ,Public Administration Review” 66/3 (2006), s. 370-385.

${ }^{18}$ C. Yang, L.C. Chen, Can organizational knowledge capabilities affect knowledge sharing behavior?, ,Journal of Information Science" 33/1 (2007), s. 95-109.

${ }^{19}$ W.A. Taylor, G.H. Wright, Organizational readiness for successful knowledge sharing: Challenges for public sector managers, „Information Resources Management Journal” 17/2 (2004), s. 22-37.

${ }^{20}$ P. Schepers, P.T. van den Berg, Social factors of work-environment creativity, ,Journal of Business and Psychology" 21/3 (2007), s. 407-428.

${ }^{21}$ A. Kankanhalli, B.C.Y. Tan, K.K. Wei, Contributing knowledge to electronic knowledge repositories: An empirical investigation, „MIS Quarterly” 29/1 (2005), s. 113-143.

${ }^{22}$ M.T. Hansen, N. Nohria, T. Tierney, What's your strategy for managing knowledge?, „Harvard Business Review" 77/2 (1999), s. 106-116.

${ }^{23}$ E. Siemsen, S. Balasubramanian, A.V. Roth, Incentives that induce task-related effort, helping, and knowledge sharing in workgroups, „Management Science” 53/10 (2007), s. 1533-1550.

${ }^{24}$ S. Kim, H. Lee, op. cit., s. 370-385.
} 
które nie potwierdziły istotnej zależności zewnętrznych motywacji (nagród opartych na osiąganych wynikach) z intensywnością dzielenia się wiedzą ${ }^{25}$.

W odniesieniu do uwarunkowań technologicznych można wskazać wyniki analiz potwierdzających, że stosowanie technologii komunikacyjno-informacyjnych ułatwia kodyfikację, integrację i upowszechnianie wiedzy organizacyjnej ${ }^{26}$. Technologie te umożliwiają szybkie wyszukiwanie, dostęp i pozyskiwanie wiedzy, a także wspierają komunikowanie i współpracę pomiędzy pracownikami przedsiębiorstwa ${ }^{27}$. Wykorzystywanie internetowych baz danych, intranetu czy wirtualnych społeczności umożliwia rozszerzanie sieci społecznych niezależnie od barier geograficznych, jednocześnie poprawiając skuteczność dzielenia się wiedzą ${ }^{28}$.

Przedstawione wyniki badań dotyczących uwarunkowań dzielenia się wiedzą wskazują na wieloaspektowość i złożoność omawianej problematyki. Niejednoznaczne wnioski mogą sugerować, że istnieją czynniki kontekstowe wpływające na poszczególne analizowane zależności.

Wśród uwarunkowań mogących wpływać na specyfikę i intensywność dzielenia się wiedzą $\mathrm{w}$ przedsiębiorstwach należałoby uwzględnić otoczenie, w którym funkcjonuje dany podmiot. Dotyczy to z jednej strony niepewności otoczenia charakteryzującego się określoną złożonością, zmiennością i wrogością ${ }^{29}$. Im większa niepewność otoczenia, tym większa powinna występować potrzeba pozyskiwania i dzielenia się wiedzą niezbędną dla przetrwania przedsiębiorstwa $\mathrm{w}$ turbulentnych i nieprzewidywalnych warunkach. Z kolei specyfika i poziom dzielenia się wiedzą mogą wynikać z intensywności współpracy międzyorganizacyjnej z podmiotami w otoczeniu przedsiębiorstwa, w szczególności z klientami, dostawcami, konkurentami, jednostkami naukowymi (instytutami badawczymi, uczelniami wyższymi) czy firmami konsultingowymi. Dzielenie się wiedzą między pracownikami może mieć decydujące znaczenie dla skutecznej absorpcji pozyskiwanej w ten sposób wiedzy zewnętrznej ${ }^{30}$. Rozpoznanie, w jaki sposób omawiane zagadnienia związane $\mathrm{z}$ otoczeniem organizacji wpływają na dzielenie się wiedzą, stanowiło przedmiot badań przedstawionych w dalszej części niniejszego artykułu.

\section{MATERIALY I METODY}

W nawiązaniu do podjętych w niniejszym artykule rozważań przeprowadzono badania empiryczne obejmujące problematykę dzielenia się wiedzą w przedsiębiorstwach działających w Polsce. Badania te zrealizowano w drugiej połowie 2013 r. Wykorzystaną meto-

${ }^{25}$ T.J. Chang, S.P. Yeh, I.J. Yeh, The effects of joint reward system in new product development, „International Journal of Manpower" 28/3-4 (2007), s. 276-297.

${ }^{26}$ S.W. Song, An internet knowledge sharing system, ,Journal of Computer Information Systems” 42/3 (2002), s. 25-30.

${ }^{27}$ M. Huysman, V. Wulf, IT to support knowledge sharing in communities: toward a social capital analysis, „Journal of Information Technology” 21/1 (2006), s. 40-51.

${ }^{28}$ S.L. Pan, D.E. Leidner, Bridging communities of practice with information technology in pursuit of global knowledge sharing, ,Journal of Strategic Information Systems” 12/1 (2003), s. 71-88.

${ }^{29}$ F.J. Milliken, Three Types of Perceived Uncertainty About the Environment: State, Effect and Response Uncertainty, „Academy of Management Review” 12/1 (1987), s. 133-143; S. Sharma, J.A. Aragón-Correa, A contingent resource-based view of proactive corporate environmental strategy, „Academy of Management Review" 28/1 (2003), s. 71-88

${ }^{30}$ A. Ryszko, Pozyskiwanie wiedzy zewnętrznej a ekoinnowacyjność MŚP na przykładzie branży ochrony środowiska, „Zeszyty Naukowe Politechniki Śląskiej, Organizacja i Zarządzanie” 2013/67, s. 29-44. 
dą badawczą były telefoniczne wywiady wspomagane komputerowo (CATI, Computer Assisted Telephone Interview). Wywiady przeprowadzono $\mathrm{z}$ właścicielami przedsiębiorstw lub członkami ich zarządów oraz osobami decyzyjnymi w danej organizacji. Odpowiedzi na pytania obejmujące przedmiot niniejszego artykułu uzyskano od przedstawicieli 292 przedsiębiorstw - w tym 47 dużych, 95 średnich i 150 małych.

Zakres tematyczny badań obejmował organizacyjne praktyki dotyczące dzielenia się wiedzą $\mathrm{w}$ przedsiębiorstwach. Wyboru analizowanych praktyk dokonano na podstawie modyfikacji narzędzia opracowanego przez Calantone i in. ${ }^{31}$ oraz I-Chieh Hsu ${ }^{32}$. Przedstawiciele badanych przedsiębiorstw odnosili się do stwierdzeń charakteryzujących stopień zaawansowania poszczególnych praktyk w siedmiostopniowej skali Likerta. W tej samej skali charakteryzowali oni ponadto intensywność współpracy międzyorganizacyjnej (uwzględniając oddzielnie współpracę z dostawcami, klientami, konkurentami i innymi przedsiębiorstwami o podobnym profilu działalności, jednostkami naukowymi oraz firmami konsultingowymi i ekspertami), a także poziom niepewności otoczenia (charakteryzowany między innymi postrzeganą trudnością przewidywania popytu na rynku, trudnością przewidywania preferencji klientów czy trudnością przewidywania przyszłych wymagań i regulacji prawnych).

Do statystycznego opisu uzyskanych wyników badań wykorzystano podstawowe parametry opisowe. Badanie statystycznej istotności zróżnicowania analizowanych zmiennych w wyodrębnionych dla potrzeb badań grupach przedsiębiorstw przeprowadzono przy zastosowaniu jednoczynnikowej analizy wariancji ANOVA. Obliczeń dokonano z wykorzystaniem programu Statistica 10.

\section{PREZENTACJA WYNIKÓW PRZEPROWADZONYCH BADAŃ EMPIRYCZNYCH I DYSKUSJA}

W ramach przeprowadzonych badań uwzględniono osiem organizacyjnych praktyk dotyczących dzielenia się wiedzą. Zmienne opisujące wspomniane praktyki wraz z określeniem stopnia ich nasilenia w badanych przedsiębiorstwach przedstawiono w tabeli 1 .

$\mathrm{W}$ odniesieniu do analizowanych praktyk przedstawiciele badanych podmiotów wskazali przede wszystkim podkreślanie przez najwyższe kierownictwo znaczenia dzielenia się wiedzą $\mathrm{w}$ przedsiębiorstwie ( $\overline{\mathrm{x}}_{\mathrm{Dw} 1}=5,24$ ), pełnienie przez pracowników wyższego szczebla roli mentorów dla młodszych pracowników $\left(\bar{x}_{\mathrm{DW}_{2}}=5,19\right)$, a także analizowanie nieudanych przedsięwzięć i rozpowszechnianie wśród pracowników wyciągniętych z nich wniosków ( $\left.\overline{\mathrm{x}}_{\mathrm{DW} 4}=5,14\right)$. W zdecydowanie najmniejszym zakresie wskazywano natomiast stosowanie zachęt dla pracowników do dzielenia się wiedzą $\left(\overline{\mathrm{x}}_{\mathrm{DW} 7}=4,53\right)$ oraz systemów informatycznych ułatwiających dzielenie się wiedzą między pracownikami ( $\bar{x}_{\text {Dws }}=4,58$ ).

Następnie badane przedsiębiorstwa pogrupowano w zależności od postrzeganej niepewności otoczenia oraz poziomu intensywności współpracy międzyorganizacyjnej. Przedsiębiorstwa podzielono na podstawie mediany uzyskanej dla zmiennych charakteryzujących odpowiednio poziom niepewności otoczenia oraz intensywność współpracy międzyorganizacyjnej. Uzyskano w ten sposób grupy przedsiębiorstw o postrzeganej

\footnotetext{
${ }^{31}$ R.J. Calantone, S.T. Cavusgil, Y. Zhao, Learning orientation, firm innovation capability, and firm performance, ,Industrial Marketing Management” $31 / 6$ (2002).

${ }^{32}$ I.Ch. Hsu, Knowledge sharing practices as a facilitating factor for improving organizational performance through human capital: A preliminary test, ,Expert Systems with Applications” 35/3 (2008), s. 1316-1326.
} 
małej i dużej niepewności otoczenia, a także grupy przedsiębiorstw o małej i dużej intensywności współpracy międzyorganizacyjnej. Poziom zaawansowania analizowanych praktyk dotyczących dzielenia się wiedzą $\mathrm{w}$ wyodrębnionych grupach przedsiębiorstw zaprezentowano w tabeli 1.

Przeprowadzone jednoczynnikowe analizy wariancji ANOVA wykazały, że występuje istotne zróżnicowanie zaawansowania wszystkich analizowanych praktyk, zarówno biorąc pod uwagę poziom postrzeganej niepewności otoczenia $(\mathrm{p}<0,01)$, jak i intensywność współpracy międzyorganizacyjnej $(\mathrm{p}<0,001)$. W odniesieniu do grup przedsiębiorstw wyodrębnionych na podstawie kryterium postrzeganej niepewności otoczenia największe i najistotniejsze zróżnicowanie wystąpiło w odniesieniu do stosowania zachęt dla pracowników do dzielenia się wiedzą $\left(\overline{\mathrm{x}}_{\mathrm{DW} 7 \mathrm{NM}}=4,19, \overline{\mathrm{x}}_{\mathrm{DW} \text {-ND }}=4,86\right)$, posiadania systemów informatycznych ułatwiających dzielenie się wiedzą między pracownikami $\left(\bar{x}_{\text {Dw5-NM }}=4,26\right.$, $\left.\overline{\mathrm{X}}_{\mathrm{DW} 5-\mathrm{ND}}=4,90\right)$ oraz pełnienia przez pracowników wyższego szczebla roli mentorów dla młodszych pracowników $\left(\overline{\mathrm{x}}_{\mathrm{DW} 2-\mathrm{NM}}=4,91, \overline{\mathrm{x}}_{\mathrm{DW} 2 \mathrm{ND}}=5,47\right) . \mathrm{W}$ grupach przedsiębiorstw wyodrębnionych na podstawie intensywności współpracy międzyorganizacyjnej wystąpiło jeszcze większe i istotniejsze zróżnicowanie zaawansowania analizowanych praktyk. Dotyczyło to w szczególności posiadania systemów informatycznych ułatwiających dzielenie się wiedzą między pracownikami $\left(\overline{\mathrm{x}}_{\text {Dw5-IwM }}=3,67, \overline{\mathrm{x}}_{\text {Dw5-IwD }}=5,49\right)$, zapewniania pracownikom udziału w szkoleniach i programach rozwoju $\left(\bar{x}_{\text {Dw8-IwM }}=3,94, \bar{x}_{\text {Dw8-IwD }}=5,62\right)$, a także stosowania zachęt dla pracowników do dzielenia się wiedzą ( $\overline{\mathrm{x}}_{\text {DW7-IWM }}=3,75$, $\left.\overline{\mathrm{x}}_{\mathrm{DW} \mathrm{IWD}}=5,30\right)$.

Wyniki przeprowadzonych analiz wskazują, że przedsiębiorstwa w warunkach wzmożonej niepewności otoczenia zwracają większą uwagę na rozwój praktyk dzielenia się wiedzą. Intensywność dzielenia się wiedzą między pracownikami ma również ścisły związek z intensywnością współpracy międzyorganizacyjnej przedsiębiorstw. Warto w tym miejscu nadmienić, że wyniki innych badań wykazały, że przedsiębiorstwa funkcjonujące $\mathrm{w}$ warunkach szybkich zmian i niestabilności otoczenia są w większym stopniu zainteresowane współpracą międzyorganizacyjną i bliskimi relacjami $\mathrm{z}$ partnerami w łańcuchu dostaw niż przedsiębiorstwa działające w warunkach stabilnych ${ }^{33}$. Można zatem stwierdzić, że dzielenie się wiedzą w przedsiębiorstwie, oprócz wymiany i upowszechniania wiedzy wcześniej zakumulowanej przez pracowników, stanowi także jedną z kluczowych przesłanek skutecznej absorpcji wiedzy zewnętrznej pozyskiwanej w ramach współpracy międzyorganizacyjnej, zwiększając możliwości jej praktycznego zastosowania. Wspomniane zdolności organizacyjne mogą być zatem znaczącym wsparciem dla przedsiębiorstw, szczególnie w odniesieniu do opracowywania i wdrażania innowacji, które są najczęściej decydującym źródłem uzyskiwania i utrzymywania przewagi konkurencyjnej w otoczeniu charakteryzującym się złożonością, zmiennością i wrogością. Potwierdzają to wyniki badań, zgodnie z którymi zaawansowanie praktyk dzielenia się wiedzą istotnie wpływa zarówno na jakość i szybkość procesu innowacyjnego, jak i osiągane przez przedsiębiorstwa wyniki operacyjne i finansowe ${ }^{34}$.

\footnotetext{
${ }^{33}$ B. Fynes, S.D. Burca, D. Marshall, Environmental uncertainty, supply chain relationship quality and performance, ,Journal of Purchasing and Supply Chain Management” 10/5 (2004), s. 179-190.

${ }^{34}$ Z. Wang, N. Wang, Knowledge sharing, innovation and firm performance, „Expert Systems with Applications" 39 (2012), s. 8899-8908.
} 
Tabela 1. Zaawansowanie praktyk dotyczących dzielenia się wiedzą w badanych przedsiębiorstwach ogółem oraz w grupach podmiotów wyodrębnionych na podstawie intensywności współpracy międzyorganizacyjnej oraz postrzeganej niepewności otoczenia

Table 1. The advancement of knowledge sharing practices in the surveyed enterprises in general and in groups of entities classified according to the criterion of the intensity of interorganizational cooperation and the perceived environmental uncertainty

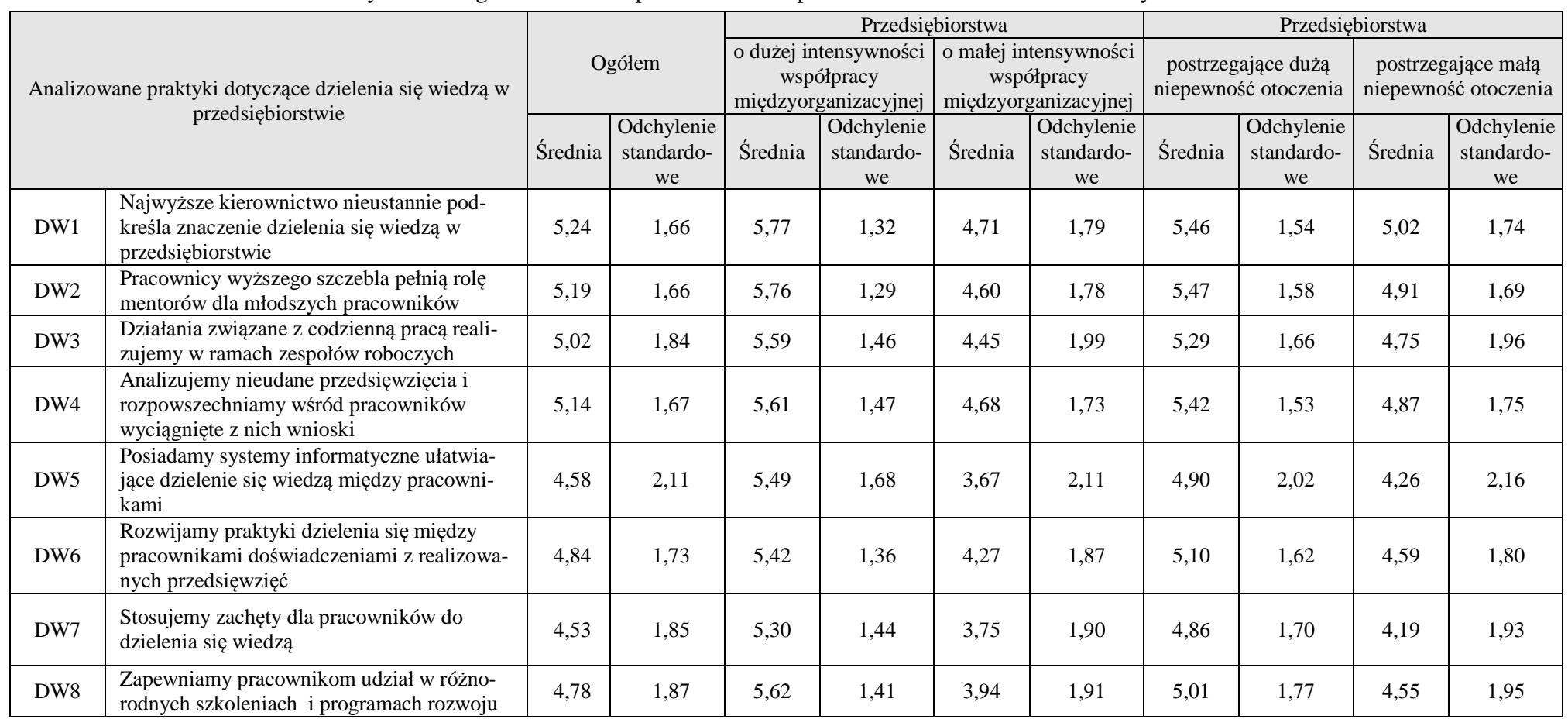

Źródło: opracowanie własne. 


\section{PODSUMOWANIE}

Dzielenie się wiedzą w przedsiębiorstwach stanowi podstawę organizacyjnego uczenia się. Proces ten przebiega na poziomach: pojedynczych osób, grupowym, organizacyjnym i międzyorganizacyjnym. W literaturze przedmiotu występują różnorodne ujęcia uwarunkowań wpływających na specyfikę i zaawansowanie praktyk dzielenia się wiedzą. Można wśród nich wyróżnić czynniki indywidualne, interpersonalne, organizacyjne i technologiczne. Dotychczasowe badania potwierdzają ich wieloaspektowy i złożony, ale zarazem nie do końca jednoznaczny wpływ, co sugeruje istnienie czynników kontekstowych oddziaływujących na istniejące w tym obszarze zależności.

W niniejszym artykule przyjęto, że wśród takich kontekstowych uwarunkowań należałoby uwzględnić otoczenie, w którym funkcjonuje dane przedsiębiorstwo (jego niepewność), a także intensywność współpracy międzyorganizacyjnej. $\mathrm{Z}$ przeprowadzonych badań wynika, że stopień postrzeganej niepewności otoczenia oraz intensywność współpracy międzyorganizacyjnej pozytywnie wpływają na poziom zaawansowania praktyk dzielenia się wiedzą w przedsiębiorstwach. Szczególnie dotyczy to stosowania zachęt dla pracowników do dzielenia się wiedzą, posiadania systemów informatycznych ułatwiających dzielenie się wiedzą między pracownikami, zapewniania pracownikom udziału $\mathrm{w}$ szkoleniach i programach rozwoju oraz odgrywania przez pracowników wyższego szczebla roli mentorów dla młodszych pracowników.

Reasumując przeprowadzone badania, należy stwierdzić, że rozwój praktyk organizacyjnego dzielenia się wiedzą nie tylko usprawnia wymianę $\mathrm{i}$ upowszechnianie w przedsiębiorstwie wiedzy wcześniej zakumulowanej przez jego pracowników, ale również poprawia skuteczność absorpcji wiedzy zewnętrznej pozyskiwanej w ramach współpracy międzyorganizacyjnej. Stanowi to istotną przesłankę dla przetrwania przedsiębiorstwa $\mathrm{w}$ turbulentnym i nieprzewidywalnym otoczeniu. Zaawansowanie tych procesów wpływa bowiem na jakość i szybkość wprowadzania innowacji, które są najczęściej decydującym źródłem uzyskiwania i utrzymywania przewagi konkurencyjnej.

\section{LITERATURA}

[1] Alavi M., Leidner D.E., Knowledge management and knowledge management systems: conceptual foundations and research issues, ,MIS Quarterly” 25/1 (2001).

[2] Ardichvill A., Page V., Wentling T., Motivation and barriers to participation in virtual knowledge-sharing communities of practice, „Journal of Knowledge Management” 7/1 (2003).

[3] Bakker M., Leenders R.T.A.J., Gabbay S.M., Kratzer J., van Engelen J.M.L., Is trust really social capital? Knowledge sharing in product development projects, ,The Learning Organization" 13/6 (2006).

[4] Bitkowska A., Innowacje w zarzadzaniu wiedza w sektorze MSP, [w:] Podejście innowacyjne w zarzadzaniu, red. R. Nowacki, M.W. Staniewski, Difin, Warszawa 2010.

[5] Bordia P., Irmer B.E., Abusah D., Differences in sharing knowledge interpersonally and via databases: The role of evaluation apprehension and perceived benefits, „European Journal of Work and Organizational Psychology" 15/3 (2006).

[6] Cabrera A., Collins W.C., Salgado J.F., Determinants of individual engagement in knowledge sharing, ,International Journal of Human Resource Management” 17/2 (2006). 
[7] Calantone, R.J., Cavusgil, S.T., Zhao, Y., Learning orientation, firm innovation capability, and firm performance, „Industrial Marketing Management” $31 / 6$ (2002).

[8] Chang T.J., Yeh S.P., Yeh I.J., The effects of joint reward system in new product development, „International Journal of Manpower” 28/3-4 (2007).

[9] Fynes B., Burca S.D., Marshall D., Environmental uncertainty, supply chain relationship quality and performance, „Journal of Purchasing and Supply Chain Management” 10/5 (2004).

[10] Hansen M.T., Nohria N., Tierney T., What's your strategy for managing knowledge?, „Harvard Business Review" 77/2 (1999).

[11] Hsu I.Ch., Knowledge sharing practices as a facilitating factor for improving organizational performance through human capital: A preliminary test, „Expert Systems with Applications” 35/3 (2008).

[12] Huysman M., Wulf V., IT to support knowledge sharing in communities: toward a social capital analysis, ,Journal of Information Technology” 21/1 (2006).

[13] Kankanhalli A., Tan B.C.Y., Wei K.K., Contributing knowledge to electronic knowledge repositories: An empirical investigation, „MIS Quarterly” 29/1 (2005).

[14] Kim S., Lee H., The impact of organizational context and information technology on employee knowledge-sharing capabilities, „Public Administration Review” 66/3 (2006).

[15] Lin H.F., Knowledge sharing and firm innovation capability: an empirical study, „International Journal of Manpower" 28/3-4 (2007).

[16] Lin H.F., Lee G.G., Perceptions of senior managers toward knowledge-sharing behaviour, „Management Decision” 42/1 (2004).

[17] Milliken F.J., Three Types of Perceived Uncertainty About the Environment: State, Effect and Response Uncertainty, „Academy of Management Review” 12/1 (1987).

[18] Ojha A.K., Impact of team demography on knowledge sharing in software project teams, „South Asian Journal of Management” 12/3 (2005).

[19] Pan S.L., Leidner D.E., Bridging communities of practice with information technology in pursuit of global knowledge sharing, ,Journal of Strategic Information Systems” 12/1 (2003).

[20] Ryszko A., Pozyskiwanie wiedzy zewnętrznej a ekoinnowacyjność MŚP na przykładzie branży ochrony środowiska, „Zeszyty Naukowe Politechniki Śląskiej”, „Organizacja i Zarządzanie”, 2013/67.

[21] Sawng Y.W., Kim S.H., Han H.S., $R \& D$ group characteristics and knowledge management activities: A comparison between ventures and large firms, „International Journal of Technology Management” 35/1-4 (2006).

[22] Schepers P., van den Berg P.T., Social factors of work-environment creativity, „Journal of Business and Psychology" 21/3 (2007).

[23] Sharma S., Aragón-Correa J.A., A contingent resource-based view of proactive corporate environmental strategy, „Academy of Management Review”28/1 (2003).

[24] Siemsen E., Balasubramanian S., Roth A.V., Incentives that induce task-related effort, helping, and knowledge sharing in workgroups, ,Management Science” 53/10 (2007).

[25] Sondergaard S., Kerr M., Clegg C., Sharing knowledge: Contextualising socio-technical thinking and practice, „The Learning Organization” 14/5 (2007).

[26] Song S.W., An internet knowledge sharing system, „Journal of Computer Information Systems" 42/3 (2002).

[27] Taylor W.A., Wright, G.H., Organizational readiness for successful knowledge sharing: Challenges for public sector managers, „Information Resources Management Journal” 17/2 (2004). 
[28] van den Hooff B., van Weenen F.D.L., Committed to share: commitment and CMC use as antecedents of knowledge sharing, ,Knowledge and Process Management” 11/1 (2004).

[29] Wang Z., Wang N., Knowledge sharing, innovation and firm performance, ,Expert Systems with Applications" 2012/39.

[30] Wasko M.M., Faraj S., Why should I share? Examining social capital and knowledge contribution in electronic networks of practice, „MIS Quarterly” 29/1 (2005).

[31] Yang C., Chen L.C., Can organizational knowledge capabilities affect knowledge sharing behavior?, „Journal of Information Science” 33/1 (2007).

Artykuł powstał w wyniku realizacji projektu sfinansowanego ze środków Narodowego Centrum Nauki przyznanych na podstawie decyzji DEC 2011/01/D/HS4/03997, a także pracy statutowej BK/223/ROZ3/2015 wykonywanej w Instytucie Inżynierii Produkcji na Wydziale Organizacji i Zarządzania Politechniki Śląskiej.

\section{KNOWLEDGE SHARING IN ENTERPRISES - SELECTED PROBLEMS AND ITS DETERMINANTS}

The article presents considerations concerning the selected issues and determinants of knowledge sharing in enterprises. On the basis of literature review multifaceted, complex and ambiguous influence of individual, interpersonal, organizational and technological factors on knowledge sharing has been recognized. The results of the research carried out in enterprises operating in Poland have been presented then. Its main objective was to answer the question whether the intensity of interorganizational cooperation and perceived environmental uncertainty affects the intensity of knowledge sharing.

The conducted analyses have shown that both the intensity of interorganizational cooperation and the level of perceived environmental uncertainty significantly influence the level of development of analyzed practices. The intensity of interorganizational cooperation mostly influences the scope of use of information systems facilitating knowledge sharing, the provision of training and development programs and the implementation of incentives to encourage knowledge sharing. The perceived environmental uncertainty mostly affects the extent of utilization of incentives for employees to encourage knowledge sharing, utilization of information systems facilitating the knowledge sharing as well as the extent to which enterprises use senior personnel to mentor junior employees.

It has been pointed out that the development of interorganizational knowledge sharing practices can be an important prerequisite for the survival of the enterprise in turbulent and unpredictable environment. The increased intensity of knowledge sharing between employees may also enhance the efficiency of the absorption of external knowledge acquired within interorganizational cooperation. These processes have particular importance in implementation of innovation enabling the gaining and maintaining competitive advantage.

Keywords: knowledge sharing, determinants of knowledge sharing, interorganizational cooperation, environmental uncertainty, enterprise

\section{DOI: 10.7862/rz.2015.mmr.26}

Tekst złożono w redakcji: kwiecień 2015

Przyjęto do druku: lipiec 2015 